\title{
The Crisis of Climate and Immigration in Amitav Ghosh's Gun Island
}

\author{
Trina BOSE ${ }^{1}$ (1), Amrita SATAPATHY2 ${ }^{2}$
}

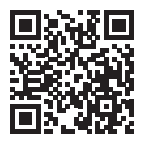

'Doctoral Research Scholar of English, School of Humanities, Social Science and Management, IIT, Bhubaneswar, India ${ }^{2}$ Assistant Professor of English, School of Humanities, Social Science and Management, IIT Bhubaneswar, India

ORCID: T.B. 0000-0001-7699-5823 A.S. $0000-0002-5742-6665$

\section{Corresponding author:}

Trina BOSE,

Room No- 217, Ganga Hall of Residence, Indian Institute of Technology, Bhubaneswar, Jatani, Odisha 752050

E-mail: tb15@iitbbs.ac.in

Submitted: 01.02.2021

Revision Requested: 21.04.2021 Last Revision Received: 05.05.2021 Accepted: 15.07.2021

Citation: Bose, T., \& Satapathy, A. (2021) The crisis of climate and immigration in Amitav Ghosh's Gun Island. Litera, 31(2), 473-489.

https://doi.org/10.26650/LITERA2021-871879

\begin{abstract}
Human migration, a socio-political phenomenon in contemporary times, refers to the journey of people across international borders or within their own country. Such journeys arise from varied ecological, social, political, religious, and economic factors. "In this globalize (sic) world, where everything seems to be global, migration is also changing its nature and forms which it takes" (UKEssays, 2018, para. 4). Even though human migration is not new, "undocumented, unauthorized, or illegal migration is a recent phenomenon" (Donato \& Massey, 2016, p. 9). Illegal immigrants who undergo political unrest and social turmoil during migration are often sufferers of identity crisis, imprisonment, torture, and exploitation through bonded labour. Falsification of identity papers, drug and arms trafficking, forced prostitution, and human trafficking are some salient features of undocumented migration throughout the world. Amitav Ghosh's Gun Island (2019) undertakes an exploratory journey into the present globalized world of anthropogenic climate metamorphoses that trigger excruciating illegal migrations from the Indian Sundarbans, the mangrove region. It is also the saga of many other undocumented migrants from various developing countries, who illegally migrate to the West in search of employment and opportunity but miserably fall victims to human trafficking, xenophobia, and imprisonment. The paper focuses on the socio-economic, political, and climatological reasons for, and the consequences of, the illegal migrations of the underprivileged people portrayed in the text under discussion, by situating them within the framework of the contemporary era of capitalist globalization.
\end{abstract}

Keywords: Climate, employment, globalization, human trafficking, illegal migration 


\section{Introduction}

The global occurrence of human migration is undoubtedly one of the most complex areas of concern that international political decision-makers and theorists are currently investigating. Human migration is "a social process that involves the consensual demarcation of lines in space by a human community that is ratified, supervised, and enforced by civil authority" (Massey, 2010, p. 125). International migrants are classified as legal immigrants, illegal immigrants, and refugees. Undocumented or illegal migration "...emerged as a structural feature of the second era of capitalist globalization, which emerged in the late twentieth century and was characterized by international market integration" (Donato \& Massey, 2016, p. 7). According to Martin Baldwin-Edwards, "illegal migration is simple to define: it is migration that occurs outside of the legal-institutional frameworks established by states" (2008, p. 1449). The term 'undocumented migrants' refers to those who illegally move from their home country to other countries crossing national or continental boundaries without proper legal documents. These are people who tend to overstay their visa or work permit, violating some or all of the conditions related to their immigration status. Some fall under the category of failed asylum seekers or immigrants who have lost the right to appeal further and have illegally extended their stay overseas. Undocumented migrants travel in search of work and lucrative opportunities in a foreign country. However, during the course of migrating, or at some point thereafter, they may undergo various ordeals arising from human trafficking, political suppression, xenophobia, anti-immigration policies, and exploitation of labour.

Amitav Ghosh's recent novel Gun Island (2019) depicts the anthropogenic climate catastrophes in the era of socio-economic and cultural globalization and the consequent plight and illegal migration of the indigenous people of the Sundarbans in India. Simultaneously, it showcases the dilemma of disadvantaged people of numerous other countries and continents, who illegally travel by crossing national as well as international boundaries. It deals with the audacious, hazardous, and illegal border-crossing of numerous people travelling from the Middle East, Africa, Bangladesh, and Pakistan to Western cities. Except for the illegal migration from the Sundarbans, the reasons behind the illegal movements of refugees from other developing countries are not overtly revealed in the text. But the sufferings of the undocumented migrants from those countries, which are vividly portrayed in the novel, can be discussed with those of the climate-affected migrants from the Sundarbans of India and Bangladesh because all of them travel illegally in search of job opportunities. They get victimized by trafficking 
which is"... defined as smuggling plus coercion or exploitation, as when women agree to be taken unlawfully across borders to be hostesses and wind up as prostitutes, or migrant workers wind up in slave or indentured conditions to repay smuggling fees" (Martin \& Miller, 2000, p. 969). The text can be interpreted as a critique on contemporary global concerns like human-induced climate change, illegal border crossings, the politics of migration, and human trafficking.

\section{Aims and Methodology}

Gun Island deals with the ever-pervasive phenomena of climate change and human migration. This paper particularly aims to explore the traumatic yet daring account of illegal migrants from Indian Sundarbans and several other developing countries. It also explores the socio-political and climatological reasons as well as the consequences of such migrations while at the same time interpreting how the capitalistic politics of the globalized world impact illegal migrations.

The paper aims to carry out a close reading of the text discussed here and also to analyse related passages for the investigation of these two contemporary global crises, i.e, anthropogenic climate change and illegal immigration. Textual proofs will be quite noteworthy in this context and the supporting pieces of evidence will be analysed and emphasized to bring out the quintessence of the crises of climate and immigration. Apart from a close reading of the novel discussed here, an analysis of the secondary sources on the work concerned will be carried out to further justify the focus of the research article.

\section{Findings}

The narrator and the protagonist of Gun Island, Dinanath Datta, is a Brooklyn-based rare book dealer, who visits the shrine of Manasa Devi in the Sundarbans which is depicted in the legend of the Gun Merchant (Bonduki Sadagar) - a popular Bengali folklore. On one of his trips, he comes into close contact with the hostile yet fragile ecosystem of Indian Sundarbans which is cut off from the developed regions of India. Nilima Bose who runs the Badabon trust in the Sundarbans rightly observes that "the islands of the Sundarbans are constantly being swallowed up by the sea; they're disappearing before our eyes" (Ghosh, 2019, p. 18). When she comes to know about his passion for antiquities, she requests Dinanath to visit the shrine of Manasa Devi 
before it is destroyed by rising sea levels and before the legendary story is lost to humankind forever since "temperatures are rising around the world because of global warming" (Ghosh, 2019, p. 214) causing sea-level rise. Dinanath learns about the perilous lives of the people who inhabit this mangrove region. The Sundarbans is described by Kanai Dutta, a distant relative of the narrator, as "the frontier where commerce and the wilderness look each other directly in the eye" (Ghosh, 2019, p. 8), and materialistic people come to earn profit at the cost of natural resources. According to Kanai, "...every merchant who's ever sailed out of Bengal has had to pass through the Sundarbans there's no other way to reach the sea" (Ghosh, 2019, p. 8). And the shrine of Manasa Devi was built in this swamp full of poisonous snakes because this is "exactly where the war between profit and Nature is fought" (Ghosh, 2019, p. 8).

The text brings to light the pressing ecological problems that the Sunderbans is going through. The acidification and pollution of water resources and the subsequent dead zones in the region can be interpreted as the outcome of the clash between two incompatible forces, i.e., the environment and humankind, or more appropriately, Nature and urbanization. According to Robert Diaz and Rutger Rosenberg,

The formation of dead zones has been exacerbated by the increase in primary production and consequent worldwide coastal eutrophication fueled by riverine runoff of fertilizers and the burning of fossil fuels. Enhanced primary production results in an accumulation of particulate organic matter, which encourages microbial activity and the consumption of dissolved oxygen in bottom waters. (2008, p. 926)

Pia, an Indian-American of Bengali origin monitoring the Irrawaddy dolphins in the Sundarbans, is one of the seminal characters in the text. She frequents the place often and is well versed in the topography of the area. She observes that the river water has been polluted by agricultural pollutants as well as by the dumped chemicals of a refinery. The refinery is run by a group of influential people who are unstoppable and have control over politicians and the police. According to Pia, dead zones grow "at a phenomenal pace, mostly because of residues from chemical fertilizers" (Ghosh, 2019, p. 95). Through her, the readers are made to comprehend that these zones can be as long as middle-sized countries, and a dead zone can also be found in a river, specifically where it meets the sea. 
In the Sundarbans, such water contamination and existing dead zones result in the death of fish, crabs, dolphins, and other marine life both of the river and sea. It wrecks the lives of the poor who earn their livelihood by fishing or collecting crabs. It is observed that "the proponents of the vicious circle of poverty argue that as the poor in the developing countries depend most on the natural resources for earning their livelihood, a vicious cycle of poverty - environmental degradation-poverty is created" (Radha \& Sankhyan, 2002, p. 11). In Gun Island, we see how the detrimental impacts of anthropogenic water pollution deteriorate the condition of poverty-stricken indigenous people by ruining their professions and forcing them to migrate somewhere else to survive.

This climate-induced human displacement from the Sundarbans in contemporary times resembles that of the Gun Merchant in the ancient legend of the Gun Merchant used in the text, who fled his homeland to save his life from the destructive forces of climate change symbolized by the fury and revenge of the Goddess Manasa whom the Merchant disrespected. Cinta who is an Italian historian in the text offers a pragmatic interpretation of the ancient legendary story of the Gun Merchant. The parallel journey of the climate-driven migrants of the past (the Gun Merchant) and the present (the underprivileged from the Sundarbans) elucidates that the legend is "an apocryphal record of a real journey to Venice" (Ghosh, 2019, p. 138). According to Cinta, the Merchant's "homeland, in eastern India, is struck by drought and floods brought on by the climatic disturbances of the Little lce Age; he loses everything including his family, and decides to go overseas to recoup his fortune" (Ghosh, 2019, p. 141). Pia despondently describes the present environmental condition of the Sundarbans and the world, "We're in a new world. No one knows where they belong any more, neither humans nor animals" (Ghosh, 2019, p. 97). It is portrayed that the outcomes of anthropogenic environmental devastations like global warming, sea-level rise, and water pollution pose an existential threat to all living beings on earth during the climate apocalypse.

The narrative quite authentically informs the reader that the Bhola Cyclone of 1970 had devastated the coastal areas of the Sundarbans, and the inland area called Lusibari. The villages had been demolished by the powerful storm surge. Only bare skeletons of trees were visible, and dead bodies floated everywhere, "half-eaten by wild animals" (Ghosh, 2019, p. 14). The hamlets were robbed of their inhabitants by the cyclone. The situation worsened with the immigration of refugees and people from East Pakistan, who wished to escape situations of political mayhem like the war of independence, social unrest, and the trauma of massacre. The incident aggravated the dire predicament 
of the indigenous people in the Sundarbans where there had already been a lack of freshwater, food, and health care. The precariousness of Nature and life in this coastal region of the Bay of Bengal held local people back from development, rendering them deprived and socially marginalized.

Inhabitants of the Sundarbans live a storm-tossed and cyclone-ravaged life of incessant struggle and are forced to adapt to the frequently changing climatic conditions. Horen, a fisherman from the Sundarbans, stopped his fishing business as two of his trawlers and a couple of other boats had capsized in Aila Cyclone in 2009. Farmers left the place as the soil became uncultivable due to saltwater intrusion ensuing from extreme weather events and sea-level rise. In "The Indian Sundarban Mangrove Forests: History, Utilization, Conservation Strategies and Local Perception," it is observed that "sea level rise owing to global warming, anthropogenic drivers, and land subsidence eventually affects the mangrove forest and vulnerable, coastal communities" (Ghosh et al., 2015, p. 161). One sees in Gun Island, the resolute young people of the lands taking the bold decision of moving abroad, albeit illegally, to earn money for an improved and stable life.

The number of traffickers increases after each cyclone and they come to trap the poor and earn profit by using their crisis as an opportunity; they manipulatively take women to faraway brothels and able-bodied men to worksites. It will not be fallacious to state that "in the Sundarbans, in the aftermath of climate change-intensified disasters, large-scale out-migration and a surge in trafficking ensued" (Molinari, 2017, para. 28). According to Tipu, a local boy of the Sundarbans, the downtrodden people from the Sundarbans choose to cross national boundaries illegally since they cannot easily arrange officially authorized documents like passports and visas.

Tipu, while giving justification for illegal immigration of the deprived and the marginalized to Dinanath, explains that climate change and the resultant increase in the number of destructive cyclones are two pertinent causes behind the exodus of people from the Sundarbans. The dirt-poor and illiterate people of the Sundarbans have to starve to death if they do not move out of the Sundarbans. Hence "climate change and sea-level rise are likely to make some places uninhabitable, leading to major increases in migration" (Last et al., 1998, p. 13). According to Tipu, the poor do not have money to bribe the forest guards to go to the jungle to collect honey or other forest products. Moreover, high salinity content in the land and water makes cultivation 
and fishing unsuitable professions. Katha Kartiki remarks, "... as climate change affects the availability of resources and reshapes geographical boundaries, communities will be forced to migrate to access to natural resources, and seek more productive livelihoods. This will likely drive conflict, as people struggle over limited resources and cross national borders" (2011, pp. 23-24). Gun Island showcases how in the time of climatological alterations and ecological damage, the natural resources of the mangrove region cease to be abundant, which ruins the lives of the poor of the Sundarbans leading to conspicuous mass migrations.

Tipu remarks that "the Internet is the migrants' magic carpet; it's their conveyor belt" (Ghosh, 2019, p. 61) since, in the epoch of the internet and digitalization, illegal migrants have easy access to knowledge and information. M. Moretti observes that "what is happening to the mobile communication market is a good example of positive globalization: in few years mobile phones have spread all around the world becoming a low-cost tool capable of providing wireless connectivity almost everywhere" (2011, p. 2). The illegal human migration exhibited in the text shows that this process of globalization is not free from its limitations and shortcomings because it provides illegal migrants with information which helps them plan their journey. The text highlights the drawbacks or destructive impacts of the wrong usage of technology and learning from the internet. Underprivileged people get enticed by fascinating images of a foreign country that they find on the internet. They try to illegally reach this place by forging documents. Tipu gathers information regarding irregular routes from the internet at the very time when illegal immigration is constrained by governments globally. However, such restrictions had not been so stringent when people migrated from one place to another in ancient times.

Tipu and Rafi from the Sundarbans are portrayed as having had access to technology since their childhood and as such they are adept at using modern devices like smartphones and computers. They get the idea of a better life in a foreign country also from the internet which allures them. In an interview, Amitav Ghosh remarks,

A lot of this is happening because the systems exist, and these systems are not trivial systems. The human trafficking business is the biggest clandestine industry in the world, even bigger than the drug trade. It reaches very deep into society, especially poor societies. On top of that, you have the information system. If you are a poor kid in say Bangladesh or Pakistan-both of these countries have higher rates of internet 
penetration rates than the U.S.-you see these pictures on your cheap smartphone. You have social media and you are connected to people who can help you move. These technologies are absolutely at the heart of movement. (Ramakrishnan, 2019, para. 19)

Gun Island depicts that this trend can be found even in the most backward and adverse coastal and other remote regions of India. Tipu and Rafi plan their illegal journey to Western countries in search of employment. But they get caught in the web of international politics of migration that takes away their independence and strips them of their dignity.

The text highlights that illegal immigrants become political refugees, social outcasts, and homeless and nameless entities - the exploited resources. The sordid tale of illegal migration is brought out poignantly yet starkly through two young characters - Tipu and his friend Rafi. Tipu and Rafi, along with many other illegal migrants, fall victims to smuggling which aims at "material gains from the illegal crossing of international borders and there can be consent from the individual to be moved" (Yahya, 2020, p. 2). Rafi narrates his horrific experiences of the perilous journey from the Sundarbans with Tipu. Tipu prearranged their travel with the aid of some dalals from Bangladesh. They were first taken to Dhaka. Then from Dhaka they were brought to Kolkata and were kept locked and hidden in a "connection house" (Ghosh, 2019, p. 237) in unhygienic conditions. If someone would complain or ask too many questions, that hapless victim would have been "slapped or beaten; sometimes the jackals would hit" (Ghosh, 2019, p. 237) with pistol butts.

On the third night, their journey began again in a truck, and their condition was like cows and goats without having sufficient space even to sit down. Many of them suffered from car sickness, and most of the time, they did not know about their destination. When they were close to the Pakistan border, they were asked to arrange for an extra payment of fifty US dollars each. When Tipu protested, the traffickers slapped him and shoved a stick into him. When the truck reached the Turkish border, the migrants started to run following previous instructions given to them to dodge and save their lives from the firing of the border guards. Rafi and Tipu got separated in the ensuing confusion, and they became terrified. While running, they heard the sounds of gunshots, and the shots hit some of their fellow migrants who screamed in pain lying on the track helplessly like "fallen animals" (Ghosh, 2019, p. 240). Rafi says, "there were maybe thirty 
or forty of us, running blindly, in a panic: it was like a stampede" (Ghosh, 2019, p. 240). Rafi took shelter in a hiding place with a dozen Hazaras. After being separated from Tipu, Rafi became baffled and lost as he did not know anything about the routes or where to go next. Tipu called Rafi eventually and advised him to join a group of refugees who planned to walk to Europe. Among the refugees, there were a few Bengalis, and the others were from Iraq, Syria, Afganistan, Somalia, and Pakistan. Tipu also advised him to try to reach Venice. Finally, Rafi arrived in Venice with many other illegal immigrants like himself having experienced harrowing experiences of the illegal flight from his country of origin. In this way, the illegal migrants previously obsessed with the idea of an improved life in a foreign country got disillusioned during the course of their journey. The illegal migrants crossed from an age of innocence to experiencing firsthand the notoriety of world politics and the nasty ways of the globalized world.

Both Tipu and Rafi hail from the Sundarbans, but unlike Rafi, Tipu does not suffer from poverty since he is blessed with a luxurious life even in a remote village. Pia provides Tipu and his mother Moyna with all sorts of comfort since Tipu's father who worked for Pia died while saving her life. So Tipu has not been forced to illegally migrate to earn money unlike other illegal migrants from the Sundarbans. Rather, he willingly chooses to flee his place for job opportunities in a prosperous foreign city, which he fails to get in Kolkata owing to prevailing social bias and marginalization of the natives of the Sundarbans. The narrative informs the reader that the indigenous people of this mangrove area are looked down upon in Kolkata due to their financial weakness and lack of progress. For instance, when Tipu's schoolmates in Kolkata come to know that Tipu is from the Sundarbans, they consider him only as a Dalit and start humiliating him by saying that only whores and servants come from his place. Moreover, his classmates from influential families ensure his expulsion because Tipu beats a boy for his insulting remarks about the Sundarbans.

Tipu illegally crosses the national border with forged papers, lying to his family about his job and present location. While tracking Tipu's journey, Pia who also happens to be Tipu's legal guardian contacts an NGO that deals with refugees and migrants. A member of the NGO informs Pia that Tipu's story is quite common in the present global context because"over the last couple of years there had been a huge increase in reports of teenage boys and young men leaving home without informing their families" (Ghosh, 2019, p. 183). After searching Tipu's bag Pia learns about his growing obsession for Venice and anticipates that he will end up in Venice. 
The narrative throws light on the fact that illegal migration is not a smooth process since the people immigrating illegally risk torture, deportation, detention, and falling prey to transnational organized crime. Quite paradoxically, the biblical place Sinai becomes a perilous place for illegal migrants and refugees in the present and a hub for the trade in human organs. But at the same time, one cannot overlook the fact that 'Sinai' derives from the word 'sin- $a h$ ' which means hatred. The narrative informs the reader that "the connection house was cunningly designed: the refugees' dungeon-like cells were below ground and difficult to detect" (Ghosh, 2019, p. 262). The place is full of smugglers, who claim money from refugees. If refugees are unable to pay them, they are even robbed of their organs which are sold to Europeans, highlighting the fact that the major types of exploitation of human trafficking are "prostitution, forced labour, slavery, or the removal of organs" (Väyrynen, 2003, p. 1). Ghosh depicts such types of harsh reality and brutality meted towards the refugees in the present which is comparable with that of the slave trade in the past.

According to Gisella, Cinta's niece and a documentary filmmaker, the traffickers have connections everywhere, like the criminal underworld, the highest political and judicial places, the police, and even European governments. She opines, "All these networks could be exposed. It's being said that this is the reason why so many governments don't want to accept the Blue Boat. This group of refugees may know too much" (Ghosh, 2019, p. 263). The Blue Boat is the first refugee boat going towards Italy in a long time, and the minister has thought of sending the navy if the situation demands so. The refugees are indeed unwanted because they are undocumented. But the above-mentioned argument of Gisa for not accepting those refugees does not seem completely baseless either. Besides, illegal immigration brings about conflicts between the human rights activists and the right-wing government in Venice.

The text offers insight into the strategies of the newly elected right-wing government in putting off illegal migration or the refugee crisis which is the biggest political concern in Europe. Gisella starts working on a documentary about the recent wave of humans crossing into Italy since an influx of illegal immigrants across the mountains, from the far sides of the Mediterranean and the Adriatic has been noticed. Besides, there are thousands of refugees crossing the sea in boats from Egypt and Libya. Some of them have been rescued. Many of them die. She seeks Dinanath's help as a translator for her documentary as the refugees are mostly from the Middle East, Africa, Pakistan, and Bangladesh. She informs him that in Italy and Europe, immigration and the refugee 
crisis are two current topics of socio-political discussion. She also updates Dinanath, "Our new right-wing government came to power because they promised to be tough on migration" (Ghosh, 2019, p. 145). So citizens considered illegal immigration as a major problem; they voted for the existing government to terminate undocumented immigrations.

Gisa informs Dinanath that a boatload of refugees has been spotted in the eastern Mediterranean, which seems to be moving towards the direction of Sicily. The situation can prove to be grim for the refugees as the interior minister in the newly formed government in Rome is a right-wing hardliner, who campaigned on an anti-immigration platform and will not allow the refugees to set foot in Italy by any means. This brings to light the fact that, though "the focus on cultural homogeneity was central to early anti-immigrant activity" (Diamond, 1996, p. 157), in contemporary times, it is more than that - it is a political concern.

The text draws attention to the uncertain lives of the homeless "when migrants are made scapegoats for social ills, negative and biased stereotypes are produced, reproduced and accepted as common sense" (Crush \& Ramachandran, 2009, p. 44). The refugees of the Blue Boat, who are the victims of xenophobia and hostility, violate the rules of international immigration. The Blue Boat is anticipated to be from Egypt, and the refugees are Eritreans, Egyptians, Ethiopians, Sudanese, and some Bengalis from India or Bangladesh. Gisa feels the need for a documentary to investigate the mass movement from the perspective of human rights as well as from a socio-political angle. She justly echoes the concerns of the common people all over the world - "Why are the migrants coming, in such dangerous circumstances? What are they feeling? What are their hopes? That is why a documentary is necessary" (Ghosh, 2019, p. 146).

According to Fozlul Hoque Choudhury or Palash, a Bangladeshi immigrant in the text, the human rights activists of Italy decide to stand by the refugees of the Blue Boat. They send their boats to deal with the right-wing activists who aim at driving the refugees back. Palash observes that the Blue Boat becomes symbolic of the various socio-ecological problems such as climate change, social inequality, capitalistic policies, corruption, the arms trade, the oil industry, and the sheer callousness of the world towards the afflicted refugees. The protagonist encourages Piya to "put a human face on" (Ghosh, 2019, p. 277) the anonymous refugees of the Blue Boat by throwing light on their displaced lives and struggle because they have lost their identity. It should 
also be highlighted that the refugees are characterized by heterogeneity as they are from diverse countries, cultures, and backgrounds and they have different reasons for migrating arising from a variety of socio-political factors. In short, their stories of migration are all different.

Dinanath finds that there are some similarities between the suffering of the illegal migrants of the Blue Boat and that of the indentured workers of the past, who were transported from the Indian subcontinent, and more importantly Africa, to the New World to work in plantations as labourers as part of the Atlantic slave trade. The wretched indentured labourers of the past and the refugees of the Blue Boat have a similarity in terms of afflictions during migration. The narrative informs the reader that "then, as now, trafficking in human beings had been an immensely lucrative form of commerce" (Ghosh, 2019, p. 278). However, there is a fundamental difference between the two types of displacement, i.e., mode of migration. The system of indentured labour like the former chattel slavery was controlled and directed by European imperial powers. Sometimes, the coolies and working-class did not have any idea about their destination and future. And being ignorant of law and regulations which governed their lives, they became slaves to be sold or used to serve the Empire's economic and commercial purposes. The colonial masters used and exploited the coolies and the poor and thus became the determiners of their destiny.

On the contrary, in the present time of globalization, the systems of the past differ from those of the present as the migrants from India in Venice, like Rafi, Tipu, and similar expatriates, cannot be termed as slaves, and they deliberately planned to migrate illegally. The narrative informs the reader that "the world had changed too much, too fast; the systems that were in control now did not obey any human master; they followed their own imperatives, inscrutable as demons" (Ghosh, 2019, p. 280). Cinta remarks that twenty-first-century Italians are dependent on the labour of the immigrants who have left their own countries and who ultimately clear dirty places in Italy to earn a living. The narrative informs the reader that "Bengalis have been settling in the Veneto for a long time. Earlier they came to work in the shipyards of Mestre and Marghera. But now many more have come and in Venice they do everything- they make pizzas for the tourists, they clean the hotels, they even play the accordion at street corners" (Ghosh, 2019 , p. 146). This sheds light on the fact that because of their illegal status, undocumented migrants are left only to cater to an ever-increasing global supply chain's demand for cheap labour and decreased cost of production. 
The text portrays that in contemporary times, Western countries are marked by multiculturalism and transculturalism owing to legal immigration from various parts of the world. For instance, legal immigrants like Dinanath and Pia earn their livelihood in foreign countries. They have strong friendships and emotional bonding with foreigners, and they go through varied cross-cultural experiences which enrich their lives. Besides, a large number of illegal immigrants in Venice and the refugees of the Blue Boat stand for a kind of "overturning of a century-old project that had been essential to the shaping of Europe" (Ghosh, 2019, p. 279). Many illegal refugees like Rafi and his fellow undocumented migrants successfully reach Venice and find jobs over there, often without the knowledge of the foreign government.

Ghosh juxtaposes Venice and Sundarbans subtly. Dinanath wonders, “... when I turned to look out of the window I found myself gazing down at a sight that reminded me of a patch of Bengal countryside that I had glimpsed on my last flight out of Calcutta... an estuarine landscape of lagoons, marshes and winding rivers. From that height it was possible to mistake the Venetian landscape for the Sundarbans" (Ghosh, 2019, p. 147). According to Rafi, there are some similarities between Venice and the Sundarbans in terms of the climate-induced flood, the presence of crabs in the water, and the collapsing of embankments. Dinanath and Cinta suffer horribly from the climatological flood in Venice. Dinanath is shocked, "How was it possible that in this most civilized of cities we should be so utterly alone and helpless, so completely at the mercy of the earth"? (Ghosh, 2019, p. 232). This parallel between the Sundarbans and Venice that the author draws through this juxtaposition highlights that the climate crisis is not just confined to one region, state or country. It is ever pervasive. Through the portrayals of the Sundarbans, the text showcases Venice and Los Angeles where a disastrous wildfire takes place, illustrating how the earth is gradually getting transformed into an uninhabitable place caused by anthropogenic global warming.

\section{Discussion and Conclusion}

Gun Island concentrates on an anthropocentric world of political tumult, social prejudices, economic inequality, utilitarian attitude towards Nature, pollution of water resources, climatic disasters, and increasing human displacement. The text appears rational and magical simultaneously: 
Amid the freak cyclones and oxygen-starved waters comes the story - or stories - of migration across the ages; tales of escapology, of deprivation and persecution, of impossible yearnings for a new world that bring us, inexorably, to the terrified refugees on the Mediterranean. Which is, perhaps, Ghosh's essential point... (Clark, 2019, para. 7)

The trend of undocumented migration depicted by Amitav Ghosh deals with the disadvantaged people of the Sundarbans and diverse other countries and continents trying to escape the real world to attain the ideal world of the West in the time of globalization and anthropogenic climate change.

The illegal migrants intentionally cross international boundaries to reach economically affluent countries and earn money for an improved life which they could not attain in their home countries. But such a brave yet illegal step proves deadly for them since they undergo inhuman treatment and brutal torture during migration, losing their prior social identity and being only tagged as refugees. Besides, the loss of property, malnutrition and subsequent deterioration of health, horrific deaths at the hands of traffickers, extreme fear, physical torture, and unemployment result in a deep-rooted psychological agony among the refugees. They come into contact with the seamy sides of the globalized world, its materialistic ways and capitalistic policies.

The text serves as a small window that gives the readers a glimpse into how undocumented migrants moving through irregular channels to find work get trapped in servitude and exploitation. The refugees of the Blue Boat come to know, while illegally changing countries, how several influential countries are surreptitiously linked with oppressive practices executed by various agents and traffickers in modern times. Besides, most countries vehemently oppose and thwart the incoming of refugees for various other socio-political and economic reasons:

There are several factors that lead to the implementation of immigration policies aimed at curbing 'illegal immigration,' including political, racial, terrorism, and economic factors. However, economic crisis and financial instability can lead governments to respond with stricter immigration laws, and oftentimes, undocumented immigrants are invoked as the scapegoats for these economic and financial crises. (Martinez et al., 2015, p. 948) 
The text depicts that during illegal migration many migrants get killed by border security forces or other government armed forces. However, despite all hazards, a huge number of illegal migrants arrive at their desired places, but sometimes a few of them are compelled to retreat when they are caught.

It is a surreal tale that captures the apocalyptic visions of environmental degradation and a desperate human struggle for existence in the wake of climate disaster. The illegal border-crossing of people of the Sundarbans clarifies why "environmental migration is widely viewed as one of the most dramatic consequences of climate change" (Gemenne, 2012 , p. 238). The author blends ancient myths and legends with the tales of adventurous escapism of illegal migrants from various developing countries in the present to bring out the perennial saga of human migration ensuing from global climate breakdown. The self-willed yet socio-politically or environmentally enforced illegal migrations from diverse developing countries in the time of globalization also imply a kind of renunciation of the past domination of the authoritative colonizing countries in controlling the human movement across countries. The social conflicts in Italy centered on the Blue Boat become symbolic of the world acknowledging the ever-present refugee crisis which rapidly increases in the era of anthropogenic climate change.

Peer-review: Externally peer-reviewed.

Author Contributions: Conception/Design of Study- T.B., A.S.; Data Acquisition- T.B., A.S.; Data Analysis/Interpretation- T.B., A.S.; Drafting Manuscript- T.B., A.S.; Critical Revision of Manuscript-T.B., A.S.; Final Approval and Accountability- T.B., A.S.

Conflict of Interest: The authors have no conflict of interest to declare.

Grant Support: The authors declared that this study has received no financial support.

Hakem Değerlendirmesi: Dış bağımsız.

Yazar Katkıları: Çalışma Konsepti/Tasarım- T.B., A.S.; Veri Toplama- T.B., A.S.; Veri Analizi/YorumlamaT.B., A.S.; Yazı Taslağı- T.B., A.S.; İçeriğin Eleştirel İncelemesi- T.B., A.S.; Son Onay ve Sorumluluk- T.B., A.S.

Çıkar Çatışması: Yazarlar çıkar çatışması bildirmemiştir.

Finansal Destek: Yazarlar bu çalışma için finansal destek almadığını beyan etmiştir.

\section{References}

Baldwin-Edwards, M. (2008). Towards a theory of illegal migration: Historical and structural components. Third World Quarterly, 29(7), 1449-1459. Retrieved from http://www.jstor.org/stable/20455119 
Clark, A. (2019, June 5). Gun island by Amitav Ghosh review- climate and culture in crisis. The Guardian. Retrieved from https://www.theguardian.com/books/2019/jun/05/gun-island-amitav-ghosh-review

Crush, J., \& Ramachandran, S. (2009). Xenophobia, international migration and human development. Human Development Reports, Research Paper 2009/47. 1-104. Retrieved from https://scholars.wlu.ca/cgi/ viewcontent.cgi?article $=1013 \&$ context $=$ samp

Diamond, S. (1996). Right-wing politics and the anti-immigration cause. Social Justice, 23(3 (65)), 154-168. Retrieved from http://www.jstor.org/stable/29766959

Diaz, R. J., \& Rosenberg, R. (2008). Spreading dead zones and consequences for marine ecosystems. Science, $321(5891), 926-929$.

Donato, K., \& Massey, D. (2016). Twenty-first-century globalization and illegal migration. The Annals of the American Academy of Political and Social Science, 666, 7-26. Retrieved from http://www.jstor.org/ stable/24756125

Gemenne, F. (2012). Environmental migration. In Martiniello M. \& Rath J. (Eds.), An introduction to international migration studies: Europan perspectives (pp. 237-258), Amsterdam: Amsterdam University Press.

Ghosh, A. (2019). Gun island. India: Penguin.

Ghosh, A., Schmidt, S., Fickert, T., \& Nüsser, M. (2015). The Indian Sundarban mangrove forests: History, utilization, conservation strategies and local perception. Diversity. 7 (2), 149-169. doi:10.3390/d7020149

Kartiki, K. (2011). Climate change and migration: A case study from rural Bangladesh. Gender and Development, 19(1), 23-38. Retrieved from http://www.jstor.org/stable/41305970

Last, J., Trouton, k., \& Pengelly, D. (1998). Taking our breath away: The health effects of air pollution and climate change. Vancouver, BC (Canada): David Suzuki Foundation.

Martin, P., \& Miller, M. (2000). Smuggling and trafficking: A conference report. The International Migration Review, 34(3), 969-975. doi:10.2307/2675952

Martinez, et al. (2015). Evaluating the impact of immigration policies on health status among undocumented immigrants: a systematic review. Journal of Immigrant and Minority Health, 17(3), 947-970. doi.org/10.1007/ s10903-013-9968-4

Massey D. S. (2010). Immigration statistics for the 21st century. The Annals of the American Academy of Political and Social Science, 631(1), 124-140. doi.org/10.1177/0002716210373329

Molinari, N. (2017). Intensifying insecurities: The impact of climate change on vulnerability to human trafficking in the Indian Sundarbans. Anti-Trafficking Review, 8, 50-69. doi.org/10.14197/atr.20121784

Moretti, M. (2011). Globalization of mobile and wireless communications: Bridging the digital divide. In Prasad R., Dixit S., van Nee R., \& Ojanpera T. (Eds.), Globalization of mobile and wireless communications (pp. 19-29). Dordrecht: Springer.

Radha, S., \& Sankhyan, A. S. (Eds.). (2002). Environmental challenges of the 21st century. New Delhi: Deep and Deep Publications. 
Ramakrishnan, J. R. (2019, September 10). 'Gun island' is a surreal novel about climate change and migration. Retrieved from https://electricliterature.com/gun-island-is-a-magical-realism-novel-about-climate-changeand-migration/

UKEssays. (2018, November). Effects of globalization on migration. Retrieved from https://www.ukessays.com/ essays/cultural-studies/migration-in-the-era-of-globalization-cultural-studies-essay.php?vref=1

Väyrynen, R. (2003). Illegal immigration, human trafficking, and organized crime. WIDER Discussion Paper (No. 2003/72). The United Nations University World Institute for Development Economics Research (UNU-WIDER). Retrieved from http://hdl.handle.net/10419/52839

Yahya, A. M. (2020). Irregular migration or human trafficking? The realities of cross-border population mobility in western Sudan. Sudan Brief. Retrieved from https://www.cmi.no/publications/7174-irregular-migration-orhuman-trafficking 
